\title{
Papillary, Follicular, Hurthle Cell, Poorly Differentiated, and Anaplastic Thyroid Carcinoma Pathologic TNM Finding v8
}

National Cancer Institute

\section{Source}

National Cancer Institute. Papillary, Follicular, Hurthle Cell, Poorly Differentiated, and Anaplastic Thyroid Carcinoma Pathologic TNM Finding v8. NCI Thesaurus. Code C140909.

A pathologic finding about one or more characteristics of papillary, follicular, Hurthle cell, poorly differentiated, and anaplastic thyroid carcinoma, following the rules of the TNM AJCC v8 classification system. 